\title{
REVITALISASI PERADILAN ADAT PADA MASYARAKAT NGADA BERBASIS KEARIFAN LOKAL
}

\author{
Dominikus Rato \\ Fakultas Hukum Universitas Jember \\ Jl. Kalimantan 37, Kampus Tegal Boto Jember - Jawa Timur 6812. \\ Email : ratodominikus@yahoo.com
}

\begin{abstract}
The aim of this study to develop conflict resolution options or alternatifve dispute resolution in the local-knowlegde perspective in woe community in Ngada. In the socio-cultural reality that local knowledge is plural. Diversity of local knowledge based on the local community cosmology. Conflict resolution is always directed towards harmony. With socio-legal approach was found that adat-land dispute resolution perspective on the local knowledge in Ngadhu-bhaga community oriented perspectives such. Dispute resolution pattern in the local knowledge perspectives begins in the family, if the conflict comes from inside relatives or clan. But, if the conflict is sourced from inter-community/relatives/clan, then the chairman of the indigenous, traditional elders, who called mosalaki consulted. Mosalaki role tailored to the competencies and their respective duties. The division of tasks/roles is done by itself, according to custom and personal awareness and recognized together. It is recommended that in the event of a conflict, especially indigenous lands, the functionaries traditional law, mosalaki given first before being taken to the formal justice institutions. If the decision of the mosalaki has been accepted and implemented, then taken to the legal system, the nebis in idem principles can be applied.
\end{abstract}

Key words: adat law dispute resolution, cosmology.

\begin{abstract}
Abstrak
Tujuan penulisan ini adalah untuk mengembangkan alternatif penyelesaian konflik atau sengketa melalui perspektif pengetahuan lokal di komunitas Woe di Ngada. Dalam kenyataan sosiokultural, pengetahuan lokal bersifat plural. Keberagaman pengetahuan lokal didasarkan atas kosmologi. Penyelesaian konflik diarahkan pada harmoni. Pendekatan sosio-legal menemukan bahwa perspektif yang berlaku dalam penyelesaian konflik di Ngadhubhaga merupakan penyelesaian yang berorientasi pada kehidupan komunitas. Pola penyelesaian sengketa bersumber dari keluarga apabila konflik berawal dari dalam kerabat atau klan. Namun apabila konflik merupakan sengketa antar-komunitas/kerabat/klan, maka pemimpin komunitas, tetua adat yang disebut mosalaki, bertindak selaku konsultan. Peran mosalaki bergantung pada kompetensi dan tugas-tugasnya. Pembagian tugas dilakukan oleh dirinya sendiri, bergantung pada kebiasaan, kesadaran pribadi, dan telah diketahui bersama-sama. Dalam sebuah konflik, terutama yang berkaitan dengan tanah adat, direkomendasikan untuk dapat diselesaikan terlebih dahulu oleh mosalaki sebelum menempuh jalur hukum nasional. Apabila keputusan yang diambil mosalaki dapat diterima dan diterapkan, bila selanjutnya diselesaikan melalui sistem hukum nasional, maka prinsip nebis in idem dapat diterapkan.
\end{abstract}

Kata kunci: penyelesaian sengketa hukum adat, kosmologi.

\section{A. Pendahuluan}

Sejarah masyarakat Ngada penuh dengan pengkhianatan (kedhu usu). Salah satu masalah terkait kedhu usu adalah konflik pertanahan. Dalam beberapa tahun terakhir ini, 
terjadi peningkatan kuantitas dan kualitas konflik pertanahan, atau lebih luas lagi disebut konflik agraria. Konflik ini terus berkembang dengan berbagai cara dan metode, bahkan ada keterlibatan negara di beberapa tempat. Hal ini menimbulkan tuduhan terhadap petugas hukum dan militer sebagai pelaku kriminalisasi. Kenyataan sejarah dan kondisi masa kini menumbuhkan kebutuhan revitalisasi, yang bermakna mengembalikan daya keberlakuannya sehingga kohesi sosial dapat dikembalikan dan integrasi sosial dapat dipertahankan (Dominikus Rato, 2013:5).

Tuduhan ini bukannya tanpa alasan, sebab data-data memperlihatkan hal itu. Hal ini diperparah dengan putusan-putusan hakim Peradilan Negara yang lebih cenderung kepada pemilik uang melalui cara-cara kolusi atau kolaborasi antara hakim, pengacara, dan pihak yang berduit. Hal ini dapat dilihat dari beberapa kasus hukum ketika putusan hakim yang sudah in kracht (memperoleh kekuatan hukum pasti), tetapi tidak dapat dieksekusi karena ditolak oleh masyarakat. Konflik tanah belum juga berakhir sudah muncul konflik baru antara anggota masyarakat dengan petugas hukum yang dituduh sebagai pelanggar HAM. Demikian seterusnya sehingga ketenangan, ketenteraman, dan kedamaian masyarakat terus-menerus terganggu. Oleh karena itu, upaya untuk kembali memanfaatkan 'Peradilan Adat' yang telah hidup sejak leluhur kita dan masih berfungsi efektif, terus bergulir oleh Aliansi Masyarakat Adat Nusantara.

Kasus-kasus itu sebagaimana dikatakan oleh Ganjar Pranowo (Ganjar Pranowo, 2012) seorang anggota DPR RI, meliputi: 1) penguasaan dan pemilikan atas tanah, 2) penetapan hak dan pendaftaran tanah, 3) batas/letak bidang tanah, 4) tuntutan ganti rugi eks tanah partikelir, 5) tanah ulayat, 6) tanah objek landreform, 7) pembebasan dan pengadaan tanah, dan 8) pelaksanaan putusan pengadilan (eksekusi putusan hakim).

Dari 8 kasus tanah tersebut dapat dikategorikan lagi (Ganjar Pranowo, 2012) sbb:

1. Berdasarkan sumber sengketa konflik tanah meliputi: penyerobotan tanah, sengketa batas tanah, sengketa warisan, jual-beli berkali-kali (sertifikat asli tapi palsu), sertifikat ganda, jual beli palsu, salah ukur, pengukuran tumpang tindih, penolakan terhadap eksekusi putusan pengadilan.

2. Berdasarkan objek sengketa: tanah adat (hak komunal), transmigrasi, perkebunan, kehutanan, pertambangan, TNI/POLRI, BUMN, pengadaan tanah untuk pembangunan, tanah terlantar.

3. Berdasarkan pelaku/pihak yang bersengketa: personal, masyarakat hukum adat, masyarakat, badan hukum/perusahaan, Instansi, TNI/POLRI, Aparat penegak hukum, LSM. 
4. Inkonsistensi peraturan perundang-undangan. Ketika ketentuan tentang hak-hak masyarakat hukum adat diatur di dalam Konstitusi, sedangkan peraturan perundang-undangan yang berkenaan dengan hak-hak komunalnya merupakan produk lama, tahun 1960 dan dianggap telah ketinggalan zaman, maka ada inkonsistensi hukum di dalamnya. Seharusnya peraturan perundangan yang berada di bawahnya mengacu atau berorientasi pada Konstitusinya sebab ia merupakan turunan dari Konstitusi tersebut.

Pasal 18 B ayat (2) UUD NRI Tahun 1945 berkenaan dengan aktualisasi hak-hak tradisional masyarakat adat dan identitas budaya masyarakat tradisional. Inkonsistensi peraturan perundang-undangan dapat dilihat dalam UU No. 6 Tahun 2014 tentang Desa. Dalam Pasal 103 memberi kesempatan kepada Peradilan Desa Adat. Akan tetapi, norma ini tidak dengan sendirinya menurut hukum berlaku, masih harus diperlukan Peraturan Daerah. Sebab pelaksanaan UU No. 6 Tahun 2014 itu diperlukan Peraturan Daerah yang demikian itu. Jika Peraturan Daerah itu dibuat, maka peradilan adat itu ada dan berlaku. Masalah yang diajukan adalah apakah penyelesaian sengketa tanah adat dalam perspektif hukum adat mampu menjaga kohesi social dan menjamin harmoni social serta memberi rasa keadilan?

\section{B. Metode Penelitian}

Penelitian dilakukan dengan pendekatan etnografi hukum adat merupakan aspek kebudayaan, sebagai hasil cipta, karsa, dan rasa manusia yaitu masyarakat hukum adat. Data diperoleh dari para informan melalui penelitian lapangan dengan cara wawancara mendalam. Informasi yang diperoleh di lapangan ini dianalisis secara kualitatif yaitu dengan metode hermeneutika yaitu menginterpretasi symbol-symbol berupa bahasa, letak duduk para hakim adat, ritual sebelum dan sesudah memutuskan perkara ketika rekonsiliasi dilakukan.

\section{Hasil Penelitian dan Pembahasan}

\section{Peradilan Adat di Zaman Belanda}

Peradilan adat berfungsi menyelesaikan konflik-konflik yang timbul dalam masyarakat, sekaligus melakukan tindakan preventif yaitu pendidikan hukum adat. Konsistensi peradilan adat dalam penegakan hukum yang benar dan adil merupakan pendidikan hukum nonformal. Sebelum tahun 1951 pola penyelesaian sengketa tanah adat dilakukan melalui peradilan asli yaitu Inheemse Rechtspraak. Belanda memberikan kesempatan kepada masyarakat hukum adat menyelesaikan kasus-kasus tanah adat berdasarkan hukum anak negeri (hukum bangsa pribumi). Peradilan asli ini 
berawal dari peradilan dalam suku oleh Kepala Suku/Ketua Adat. Pada masyarakat hukum adat Ngadha, jika pada tingkat ini tidak diselesaikan, maka sengketa itu dibawa ke desa dan diselesaikan oleh Kepala Desa bersama mosa laki adat. Jika pada tahap ini juga belum terselesaikan, maka perkara itu dibawa ke Peradilan Asli atau Inheemse Rechtspraak. Selain Inheemse Rechtspraak ada pula Gouvernementrechter (Landraad) yang didalamnya juga mengatur tentang Landraad yaitu Pengadilan Negeri sekarang berdasarkan Pasal 131 jo 134 I.S. Pada zaman Daendels terdapat Pasal 86 Charter (regeringreglement) voor de Aziatische besittingen van Bataafsche Republiec yang disahkan oleh Bataafsche Republiec pada tanggal 24 September 1804 sehingga disebut Charter 1804, yang menyatakan bahwa 'Susunan pengadilan untuk bangsa pribumi akan tetap tinggal menurut hukum serta adat mereka ... supaya anak negeri memperoleh keadilan dengan cepat dan baik dengan cara menambah jumlah pengadilan ...' atau berdasarkan Pasal 17 Instruksi 3 Januari 1815 dikatakan bahwa ... mereka (Komisi Jenderal) harus memeriksa kembali undang-undang serta kebiasaan tentang administrasi pengadilan untuk orang pribumi, dan membuat peraturan-peraturan tentang hal itu, yang menurut pendapat mereka baik dan perlu untuk melakukan keadilan serta untuk menurut maksud reglement ...'

Pasal 134 ayat (2): dalam hal timbul perkara hokum perdata antara orang-orang Muslim dan Hukum Adat mereka meminta penyelesaiannya, maka penyelesaian perkara tersebut diselenggarakan oleh Hakim Agama, kecuali jika Ordonansi telah menetapkan lain.” Pada Tahun 1932 ada ketentuan yang memberi kesempatan kepada hukum adat untuk digunakan dalam upaya menyelesaikan konflik tanah adat. Dasar perundang-undangan berlakunya Hukum Adat bagi Peradilan Adat yaitu Inheemse Rechtspraak yang berwenang sebagai Peradilan bagi masyarakat atau Golongan Pribumi diatur di dalam Pasal 3 Indië Stbl. 1932 No. 80 di daerah-daerah yang diberi nama "Rechtstreeks Bestuurd atau Direct Gebied" yaitu daerah-daerah yang secara langsung diperintah oleh Pemerintah Hindia Belanda. Untuk Daerah Swapraja, dasar perundang-undangan berlakunya Hukum Adat adalah Pasal 13 ayat (3) ZelfbestuursRegelen 1938 Stbl. 1938 No. 529 dan di dalam Lange Contracten (Perjanjian Jangka Panjang).

Peradilan Adat yang disinggung di dalam Indië Stbl. 1932 No. 80 yang disebutkan di atas adalah peradilan adat ang terdapat di daerah-daerah di Luar Jawa dan Madura. Stbl 1932 No. 80 lengkapnya berbunyi: "Regeling van de Inheemse Rechtspraak in Rechtstreek Bestuurd Gebied.” Untuk Hakim Adat di Jawa dan Madura yang diberi 
nama: “Dorpsrechter” dibuat Pasal 3a R.O (Rechterlijk Organisatie) dalam Indië Stbl. 1847 No. 23 jo. Stbl. 1848 No. 47, selanjutnya Pasal 3a R.O ini dimasukkan ke dalam R.O berdasarkan Indië Stbl. 1935 No. 102.

Setelah tahun 1951 dengan dikeluarkannya UU Drt. No. 1 Tahun 1951 yang mencabut Rechts Organizatie yang berdampak pada penghapusan Peradilan Asli atau Inheemse Rechtspraak dan dialihkan ke Pengadilan Negeri, banyak persoalan tanah adat, tanah warisan, dan masalah-masalah keluarga semakin meningkat. Sebabnya, pertama, Lembaga Peradilan yaitu Pengadilan Negeri terletak di Ende dan Pengadilan Tinggi (waktu itu) terletak di Denpasar. Baru awal tahun 1980-an Pengadilan Negeri dipindahkan ke Bajawa sebagai ibukota Kabupaten Ngada dan Pengadilan Tinggi dipindahkan ke Kupang sebagai ibukota Propinsi NTT; kedua, dampak dari factor pertama, adalah bertumpuknya perkara, pada titik tertentu konflik ini meledak dan melahirkan konflik baru baik secara kuantitas dan kualitas. Hingga tahun 2009, konflik social yang bersumber dari tanah adat, terus meningkat jumlahnya (Pemerintah Kabupaten Ngada, 2010). Dampaknya adalah kohesi social semakin rentan dan harmoni social terganggu. Dampak lanjutannya adalah pembangunan baik social, budaya, politik, ekonomi, penegakan hukum lemah, dan wibawa pemerintah serta kepercayaan masyarakat kepada Pemerintah terus menurun.

\section{Peradilan Adat di Zaman Kemerdekaan}

Setelah kemerdekaan lembaga peradilan adat tidak mendapat perhatian dari Negara. Dengan adanya UU No. 14 Tahun 1970, Lembaga Peradilan Adat dihapus. Hak-hak tradisional masyarakat hukum adat terhadap peradilan adat diabaikan dan dialihkan kepada Negara. Sebagai Negara Demokrasi yang berdasarkan hukum, maka hak-hak masyarakat hukum adat yaitu hak-hak komunal diatur dan dilindungi oleh Konstitusi. Sebelum Tahun 1998 yaitu sebelum Reformasi hak-hak komunal masyarakat hukum adat 'hanya' diatur dalam UU No. 5 Tahun 1960 tentang Peraturan Dasar Pokok-pokok Agraria sebagai realisasi dari UUD 1945 Pasal 33 ayat (3) yang menyangkut tanah saja. Di dalam Konstitusi yaitu UUD 1945 pada Pasal 33 ayat (3) tidak menyebut tentang hak tradisional itu. Setelah Reformasi Tahun 1998, hak tradisional masyarakat hukum adat diatur lebih jelas dalam Konstitusi yaitu Pasal 18B ayat (2) bahwa Negara mengakui dan menghormati kesatuan-kesatuan masyarakat hukum adat beserta hak-hak tradisionalnya sepanjang masih hidup dan sesuai dengan perkembangan masyarakat dan Prinsip Negara Kesatuan Republik Indonesia yang diatur dalam undang-undang. Bunyi pasal ini merupakan produk Amandemen ke-II 
UUD 1945 hasil reformasi yang sebelumnya tidak ada. Pasal ini dipertegas lagi dalam Pasal 28I ayat (3): Identitas budaya dan hak masyarakat tradisional dihormati selaras dengan perkembangan zaman dan peradaban.

Dalam konteks yang sedang dibahas, hak-hak tradisional masyarakat hukum adat mempunyai landasan konstitusional yaitu Pasal 18 B ayat (2). Salah satu hak tradisional masyarakat hukum adat itu ialah hukum adat dan peradilan adat. Dan, idenitas budaya masyarakat tradisional diatur dalam Pasal 28 I ayat (3). Hukum adat dan peradilan adat ialah idenitas budaya masyarakat tradisional. Dalam konteks yang sedang dibahas, masyarakat hukum adat identik dengan masyarakat tradisional, walaupun mungkin saja ada masyarakat tradisional yang bukan masyarakat hukum adat atau sebaliknya masyarakat hukum adat bukan masyarakat tradisional. Akan tetapi secara empiric bahwa masyarakat hukum adat itu adalah masyarakat yang masih tradisional, terlepas bahwa ada anggota masyarakatnya yang sudah mengenal cara-cara hidup modern.

Peradilan adat, dalam kehidupan sehari-hari sekalipun Peradilan Adat dihapus oleh UU No. 14 Tahun 1970, dalam kenyataannya masih tetap diakui, dilaksanakan, dan ditaati. Pada tahun 1997 (Dominikus Rato, 1997) sebuah penelitian terhadap perang antar suku. Dalam penelitian itu ditemukan dua pola penyelesaian sengketa yaitu pola penyelesaian sengketa ke dalam yang disebut fego bhoko bhogi kedhi dan pola penyelesaian sengketa tanah adat keluar yang disebut kadhi wai dheso lesa. Pola terakhir yaitu pola keluar dengan cara-cara yang digunakan adalah: a) boka goe yaitu persaingan membunuh hewan terbanyak, khususnya babi dan kerbau. Dalam cara kerja ini orang yang membunuh hewan terbanyak dialah pemenangnya; b) poke wako/poke dha atau lempar lembing. Dalam pola ini orang yang melempar lembing paling jauh dialah pemenangnya; dan, c) buu atau perang, dalam pola ini pihak yang membunuh lawannya paling banyak dialah pemenangnya. Saat ini pola yang demikian itu sudah tidak sesuai lagi karena bertentangan dengan nilai-nilai Pancasila, UUD Negara Republik Indonesia Tahun 1945, dan Hak Azasi Manusia atau azas-azas umum kemanusiaan yang berlaku umum di seluruh dunia.

\section{Suku Ngadhu-bhaga sebagai Masyarakat Adat dan Masyarakat Tradisional}

Masyarakat Ngadhu-bhaga dalam literatur-literatur Belanda atau Jerman atau resmi disebut masyarakat Ngada (Frank M. Lebar, 1972). Kata 'Ngada' berasal dari 'Ngadha' yaitu sebuah suku yang digunakan Belanda ketika menduduki wilayah ini. Ketika Belanda masuk ke wilayah ini, pusat pemerintahan secara terpusat belum ada. 
Masing-masing klan woe hidup mandiri secara otonom baik ekonomi, sosial budaya maupun politik. Woe adalah persekutuan hukum adat atau masyarakat hukum adat sebagaimana dimaksudkan oleh Van Vollenhoven, rechtsgemeenschaap. Selain pribadi komunitas ini adalah subjek hukum dari Hukum Adat.

Ketika Belanda masuk ke wilayah ini, beberapa klan menolak, terutama masyarakat Aimere sebagai pusat perdagangan hewan. Sebab dikhawatirkan Belanda akan melakukan monopoli perdagangan hewan, terutama kerbau, padahal masyarakat setempat telah mempunyai hubungan dagang dengan Makasar, Bima, dan Jawa serta Cina. Oleh karena itu, salah satu kepala suku (klan/woe) bernama Belo Waru yang dibantu adiknya Ture Waru (Daniel Dhakidae, 1995) menolak kedatangan Belanda itu. Belo Waru adalah seorang kepala suku (klan/woe) dari salah satu woe di wilayah ini dan dianggap sebagai 'primus inter pares,' disegani dan dihormati. Penolakan oleh Belo Waru ini melahirkan perang antara kedua kubu. Akan tetapi, Belanda melakukan pendekatan kepada kepala suku/klan/woe Ngadha bernama Pea Mole dan adiknya Siwe Mole, sehingga kedua kakak beradik ini mendukung Belanda. Dalam perang itu Belo Waru bersama para pendukungnya kalah, sehingga Belanda berkuasa di daerah ini. Berdasarkan kesepakatan, Belanda mengangkat Pea Mole sebagai raja dan dibantu adiknya Siwe Mole. Sebagai balas jasa Pea Mole memberikan sebidang tanah sebagai benteng sekaligus pusat pemerintahan Belanda. Benteng Belanda itu didirikan di atas salah satu bidang tanah woe Ngadha ini. Oleh karena benteng dan pusat pemerintahan Belanda berada di atas tanah woe Ngadha, maka oleh Belanda menetapkan wilayah ini sebagai wilayah Swapraja Ngadha. Oleh karena gejala bahasa, maka kata 'Ngadha' berubah menjadi Ngada dan hingga kini disebut Kabupaten Ngada. Dan sejak itu peradilan adat berada di bawah kekuasaan raja buatan Belanda Kolonial.

Dalam tulisan ini nama Ngada diubah menjadi Ngadhu-bhaga sebab symbol utama masyarakat ini adalah Ngadhu sebagai symbol bapak asal dan Bhaga adalah symbol ibu asal (Paul Arndt, 1929). Masing-masing komunitas woe memiliki Ngadhu-bhaga sebagai symbol leluhur asal mereka. Ngadhu adalah sebatang tiang lingga sebagai symbol bapak asal woe dan diberi nama sesuai nama bapak asal woe itu, demikian bhaga adalah sebuah rumah kecil (yoni) sebagai symbol ibu asal dan diberi nama sesuai nama ibu asal woe itu (Paul Arndt, 1931). Oleh karena symbol ini sangat khas dan spesifik, maka komunitas yang menjadi subjek kajian ini diberi nama komunitas Ngadhu-bhaga sebagai pengganti masyarakat Ngada. 
Komunitas Ngadhu-bhaga sebagai masyarakat hukum adat (rechtsgemeenschaap) diambil sebab mereka adalah subjek hukum adat. Sebagaimana dikatakan oleh Van Vollenhoven (1925) bahwa untuk memahami hukum adat adalah pertama dan utama kita memahami terlebih dahulu masyarakat hukum adatnya, sebab ia berfungsi subjek sekaligus sebagai denah atau bingkai yaitu legal field (Sally Falk Moore, 1993) adat itu. Sebagai subjek hukum mereka memiliki: anggota yaitu orang-orang yang bersatu karena merasa berasal dari satu ibu bapa-asal (ngadhu-bhaga), mendiami tertentu yaitu tempat dimana rang-orang itu bertempat tinggal, beranak pinak, mencari nafkah, serta dikuburkan ketika meninggal dunia; memiliki harta kekayaan baik berwujud maupun tidak berwujud; memiliki tata nilai seperti bahasa, simbol-simbol, kesenian, dan hukum adatnya; mempunyai organisasi dan pengurusnya, serta rasa keterikatan satu sama lain. Di dalam hukum adat itulah terdapat nilai, azas, dan norma yang menjadi dasar bagi masing-masing komunitas untuk menata dan menyelesaikan setiap konflik yang timbul di antara mereka. Salah satu pola penyelesaian konflik adalah musyawarah untuk mencapai mufakat yang disebut babho yang menjadi cirikhas kearifan local komunitas ini.

Babho adalah lembaga penyelesaian sengketa tidak hanya untuk tanah adat tetapi untuk semua bentuk sengketa mulai yang sederhana seperti pencemaran nama baik (wau ngaza), pemulihan nama baik karena pelecehan sexual (waja), hingga sengketa berat seperti perang antar suku, kampung, bahkan antar desa. Babho adalah salah satu pranata hukum adat yang telah mempunyai landasan konstitusional, yaitu Pasal 18 B ayat (2) UUD NRI Tahun 1945, sekaligus merupakan identitas budaya masyarakat tradisional sebagaimana Pasal 28 I ayat (3) UUD NRI Tahun 1945. Pranata adat ini menjadi satu-satunya (bukan salah satu) lembaga hukum adat yang dipercaya saat ini di masyarakat hukum adat Ngadhu-bhaga. Babho mampu menyelesaikan berbagai konflik tanah adat di daerah ini.

Konflik-konflik ini, terutama konflik tanah adat yang paling kompleks berawal dari beberapa factor, salah satu diantaranya ialah proses pencarian keadilan melalui lembaga Peradilan Negari selalu berakhir dengan kekecewaan, biaya yang mahal, dan proses yang panjang serta berbelit-belit (Kopong Paron Pius dan Dominikus Rato, 1989). Indikatornya adalah: a) putusan hakim yang telah mempunyai kekuatan hukum pasti/tetap tidak dapat dieksekusi sebab ditolak oleh masyarakat; b) ada kantor pengadilan yang dibakar, jaksa yang diseret di jalan, hakim yang ditikam dalam ruang pengadilan; c) banyak anggota masyarakat mencari caranya sendiri dengan melakukan 
eigenrichting (Dominikus Rato, 2001). Upaya menghakimi sendiri (eigenrichting) misalnya perkelahian massal, pembunuhan, atau perang (antar suku, kampung, bahkan antar kabupaten). Dampaknya adalah upaya orang untuk mencari nafkah terhambat, kepercayaan masyarakat kepada lembaga peradilan Negara berkurang, kohesi sosial renggang dan harmoni sosial terganggu, karena antar komponen bangsa ini saling curiga. Hal ini berawal dari dihapusnya Lembaga Peradilan Asli (Inheemse Rechtspraak) berdasarkan UU. Drt. No. 1 Tahun 1951 dan UU No. 14 Tahun 1970 tentang Kekuasaan Kehakiman. Berdasarkan Pasal 130 Indische Staatsregeling yang kemudian berkembang berdasarkan Staatsblad 1830 No. 80 (J.W.J Wellan,1933). Pengalihan pola penyelesaian sengketa dengan campur tangan negara melalui Lembaga Peradilan Umum itu, proses penyelesaian sengketa secara tuntas tidak pernah tercapai lagi, masih ada dendam (Mahadi, 1991). Hal ini dapat dilihat dalam beberapa perkara, seperti konflik tanah adat antara masyarakat Raja dengan Rendu Butowe di Nagekeo, antara masyarakat Doka dengan Were di Ngada, dan beberapa masyarakat di Manggarai, terakhir di Kabupaten Alor (Anto Achadiat, 1993; Samuel Clark, Ed., 2004).

Hukum adat dan kearifan local berakar pada kosmologi (Robert Wessing, 1978) masyarakat local itu. Kosmologi adalah cara pandang masyarakat local tentang diri dan lingkungan serta hubungan antara keduanya. Sebelum menganalisis pola penyelesaian sengketa terutama terlebih dahulu dipahami kosmologi masyarakat Ngadhu-bhaga sebagai landasan filosofis pola pikir, pola perkataan, dan pola perbuatan masyarakat di kawasan ini. Dan, dalam setiap perubahan sosio kultural, pola pikir, pola perkatan, dan pola perbuatan mereka selalu bergerak mengikuti ritme kosmologi masyarakat tersebut. Kosmologi berfungsi sebagai ritme yang memandu gerak perbuatan masyarakat itu untuk mencapai harmoni. Masyarakat diandaikan sebagai organisme yang hidup.

Dalam kosmologi itu, masyarakat Ngadhu-haga memiliki keyakinan bahwa antara rumah adat, tanah, dan leluhur adalah satu kesatuan yang utuh dan total. Rumah adat adalah simbol rahim ibu asal yaitu leluhur. Tanah adalah simbol kesuburan dan kesuburan bersumber pada rahim ibu bumi. Jadi, rumah adat, tanah, dan leluhur, terutama perempuan adalah satu kesatuan konsep yakni konsep kesuburan. Sehingga, dalam pandangan masyarakat Ngadhu-bhaga, model penyelesaian sengketa tanah adat harus dilakukan dalam ruang lingkup rahim ibu yaitu leluhur; dan leluhur itu berasal dari rumah induk yang diberi nama sesuai dengan nama ibu asal. Berdasarkan cara 
pandang yang demikian, maka pola penyelesaian sengketa tanah adat bersifat internal. Dengan demikian, rumah adat mempunyai peran penting dan woe merupakan komunitas/ikatan kerabat tempat yang paling tepat untuk mempertahankan kohesi social (Ter Haar Bzn, 1960). Woe adalah komunitas sosial berdasarkan pada geneologis dan membentuk masyarakat hukum adat; ia adalah subjek hukum adat itu. Para ketua-ketua adat, kepala suku, ketua rumah adat sangat fungsional untuk menjalankan proses penyelesaian sengketa tanah adat yang demikian.

\section{Alternatif Penyelesaian Sengketa Berbasis Hukum Adat dan Kearifan Lokal}

Model lama yaitu pola penyelesaian sengketa eksternal adalah model yang bertentangan dengan nilai-nilai yang terkandung dalam Pancasila dan UUD 1945. Oleh karena bertentangan dengan landasan falsafah dan konstitusional negara dan bangsa Indonesia, maka digagas model alternatif penyelesaian sengketa baru, terutama yang berkaitan dengan konflik yang bersifat eksternal. Karena secara tradisional model lama ini selalu mengarah pada perang sebagai jalan terakhir. Namun demikian, pola tersebut, walaupun kurang disetujui tetapi dalam kenyataannya telah berubah wujud dengan mengubah pola dari perang di medan terbuka ke medan yang tertutup yang secara substansi tetap saja perang yaitu perang di Pengadilan Negeri (Hans Daeng, 1985).

Model ini telah menurunkan kepercayaan masyarakat pada negara, ex ofisio Pemerintah atau Lembaga Peradilan. Oleh karena itu, untuk mengembalikan citra negara di masyarakat, maka perlu dilakukan rekonstruksi model nonlitigasi yaitu model alternatif penyelesaian sengketa di luar Lembaga Peradilan. Model ini yang secara substansi mengembalikan kepercayaan masyarakat, sebab negara telah mengadopsi cita hukum masyarakat dengan mengembalikan keseimbangan sosiokultural (Dominikus Rato, 1996).

Model gagasan ini sebagaimana hasil diskusi 2012 di Kampung Doka yang pada intinya mengatakan bahwa tujuan penyelesaian sengketa adalah untuk mengembalikan harmoni dalam sosio-kultural, secara garis besarnya, sbb:

a. Diperlukan sebuah lembaga yang berfungsi sebagai mediator, fasilitator, dan dinamisator konflik yang bertujuan mengurangi ketegangan. Disarankan diambil dari para mosa laki (tua-tua adat). Mediator bersikap objektif, arif, dan netral. Polanya adalah fego bhoko bhogi kedhi (selesaikan sengketa sesederhana mungkin), landasan filosofisnya adalah: a) feo folo lengi jawa (perdamaian lebih 
penting dari harga diri); b) pojo mogo nee uju utu (bersatu lebih berharga daripada bercerai).

b. Diperlukan sebuah lembaga rekonsiliasi. Disarankan pula lembaga ini diambil dari lembaga negara, hukum adat dan atau agama sebagai mosa meze laki lewa. Makna filosofisnya ialah mosa meze laki lewa adalah orang tua pikirannya lebih panjang (jauh ke depan), arif dan bijaksana; dan mosa peu laki pado makna filosofinya ialah pihak ketiga lebih netral jika diberi kepercayaan. Lembaga ini juga bersifat dan bersikap objektif, arif, dan netral, hanya berorientasi pada kebenaran dan keadilan.

c. Diperlukan kerjasama secara fungsional antara: negara - adat - dan gereja yang selalu berorientasi pada kepentingan masyarakat, bukan kelompok atau golongan, apalagi untuk kepentingan politis.

d. Hasil kerja dari ketiga lembaga di atas perlu diberi dasar/payung hukum dalam bentuk Peraturan Daerah.

\section{Simpulan}

Dari analisis di atas disimpulkan bahwa diperlukan model alternatif penyelesaian sengketa yang berakar pada hukum adat. Beberapa tokoh adat mengharapkan agar pemanfaatan kembali (revitalisasi) peradilan adat dilaksanakan melalui sebuah diskusi terbuka. Diskusi terbuka dengan berbagai tokoh adat, Negara, dan Gereja agar tidak ada saling curiga dan menampung semua pandangan yang berbeda. Hal ini dapat dipahami sebab pada masyarakat Ngadhu-bhaga ini terdapat 300 buah woe/clan di berbagai kampong/desa. Dan, masing-masing woe/clan ini memiliki cirikhas yang berbeda satu sama lain.

Keinginan itu sudah dilakukan melalui Seminar pada tanggal 21 - 23 Januari 2002 oleh Pemda Kabupaten Ngada bekerjasama dengan beberapa anggota LSM di Jogyakarta dan Jakarta. Hasil seminar ini kemudian dilanjutkan dengan penelitian pada Tahun 2004 dengan tujuan yang sama dan oleh kelompok yang sama, namun dalam bentuk yang berbeda yaitu kerjasama Pemda Kabupaten Ngada dan Dosendosen dari UGM dan Universitas Atmajaya Jakarta.

Sejak tahun 2006 itulah lahir semacam kesadaran untuk kembali pada hukum adat, sekalipun polanya tidak harus sama di setiap kampung atau desa. Ada upaya untuk merevitalisasi nilai-nilai budaya dalam pola penyelsaian sengketa tanah adat. Akan tetapi ada hal yang mengganjal yaitu putusan lembaga adat tidak memiliki kepastian hukum. Sekalipun pranatanya diakui dan ditaati, namun lembaganya belum memiliki 
landasan hukum secara nasional artinya hukum Negara belum mengakuinya. Dalam pertemuan itu disepakati dibentuk semua lembaga yaitu Lembaga Pemangku Adat (LPA). Akan tetapi, masyarakat tidak mempercayai lembaga tersebut. Ada 2 sebab sehingga dicurigai pembentukannya, yakni: pertama, dicurigai berlatar belakang politik, sebab masyarakat adat yaitu ketua-ketua adat, tokoh-tokoh adat tidak dilibatkan; kedua, ditolak oleh DPRD Kabupaten Ngada sebab tidak ada dasar hukumnya.

Oleh karena itu, saat ini masyarakat Ngadhu-bhaga mengharapkan agar revitalisasi lembaga penyelesaian berdasarkan hukum adat dan inventarisasi kasus-kasus yang dapat ditangani dan diselesaikan oleh para tua-tua (mosalaki), ketua-ketua adat (ketua suku), dan masyarakat adat. Dari kasus-kasus itu, kasus apakah yang boleh diselesaikan melalui lembaga adat dan manakah yang wajib diselesaikan oleh lembaga Pengadilan Negara.

\section{E. Saran}

Pada akhir kajian ini boleh dikatakan bahwa para pembuat hukum, pelaksana hukum, dan penegak hukum perlu memahami kosmologi masyarakat lokal, jika mereka menghendaki model penyelesaian sengketa tanah adat menjadi hukum yang hidup, ditaati secara sadar, dan dipertahankan secara nyata dalam masyarakat. Apabila model alternatif penyelesaian sengketa tanah adat hasil kajian ini diterima dan diterapkan perlu ada kerja sama secara fungsional antara Lembaga Peradilan Negara dengan Lembaga Alternatif Penyelesaian Sengketa nonlitigasi yang berorientasi pada kepentingan masyarakat.

Oleh karena itu, disarankan bahwa jika terjadi sebuah konflik, terutama tanah adat, maka para fungsionaris hukum adat, para mosalaki diberi kesempatan pertama sebelum dibawa ke lembaga peradilan formal. Jika putusan para mosalaki sudah diterima dan dilaksanakan, kemudian dibawa ke lembaga peradilan formal, maka azas nebis in idem dapat diberlakukan.

\section{DAFTAR PUSTAKA}

Anto Achadiat. 1993. Penyelesaian Sengketa dan Hancurnya Hubungan Kekerabatan: Kasus Sengketa Tanah pada Masyarakat Ruteng di Kabupaten Manggarai, Flores Barat, Nusa Tenggara Timur. Dalam T.O. Ihromi (penyunting) Antropologi Hukum. Sebuah Bunga Rampai. Jakarta: Yayasan Obor Indonesia.

Arndt, Paul. 1929. Die Religion der Nad'a, Antropos 24 : 817 - 861. 
739.

Bernard L Tanya. 2000. Beban Budaya Lokal menghadapi Hukum Negara: Analisis Budaya Atas Kesulitan Sosio-Kultural Orang Sabu menghadapi Regulasi Negara. Disertasi. Semarang : Program Doktor Ilmu Hukum UNDIP.

Clark, Samuel (Ed.). 2004. Bukan Sekedar Persoalan Kepemilikan. Sepuluh Studi Kasus Konflik Tanah dan Sumber Daya Alam dari Jawa Timur dan Flores. Jakarta: Conflict and Community Development Research and Analytical Program Indonesian Social Development Paper No. 4.

Daeng, J., Hans. 1985. Pesta, Persaingan dan Harga Diri pada Beberapa Kelompok Etnis di Flores. Dalam Michael R. Dove (peny.) Peranan Kebudayaan Tradisional Indonesia Dalam Modernisasi, hal. 287 - 316. Jakarta : Yayasan Obor Indonesia.

Daniel Dhakidae. 1995. Pendekatan Historis Terhadap Pembangunan Ngadhu-Flores. Makalah Seminar - Simposium dalam Kerja sama Pemerintah Tingkat II NgadhuKanwil Depertemen Pertanian NTT. Bajawa: Pemda Tingkat II Ngadhu-Kanwil Deptan NTT.

Ganjar Pranowo, 2012, Perlindungan Hak atas Tanah \& Beberapa Gagasan dalam RUU Pertanahan. Jakarta: Universitas Trisakti. Makalah ini disampaikan dalam Simposium di Universitas Trisakti tanggal 8 - 11 November 2012.

Dominikus Rato. 1996. Tanah Sebagai Obyek Pewarisan Pada Masyarakat Ngada: Makna dan Dinamikanya (sebuah Kajian Antropologi Hukum). Tesis. Surabaya: Program Pascasarjana Universitas Airlangga. - 1997. Peranan Institusi Hukum Adat Dalam Upaya Penyelesaian Sengketa Tanah Adat Menurut Hukum Adat Ngadha. Jember: Lemlit. Sumber Dana: Kerjasama Pemda Ngada - LPM UNEJ.

2001. Menggugat Pertanggungjawaban Hukum Perilaku Birokrasi Pasca Orde Baru: Kajian Terhadap Keangkuhan Birokrasi dalam Proses Pelepasan Tapol/Napol. Dalam Achmad Gunaryo dan I.S. Soesanto, (Ed) Hukum, Birokrasi, \& Kekuasaan di Indonesia. Semarang: Walisongo Research Intitute (WRI), hal. 114-137.

2013. Konflik Hukum Di Kebun Sawit: Politik Hukum Pertanahan Dalam Rangka Pengembangan Sawit Lestari. Dalam Jurnal “Hukum dan Masyarakat” Edisi IV, No. 12.

Kopong Paron Pius dan Dominikus Rato. 1989. Kajian terhadap Pelaksanaan Azas Peradilan Cepat, Sederhana, dan Biaya Murah pada Beberapa Pengadilan Negeri di Wilayah Ex Karesiden Besuki. Jember: Lemlit - UNEJ.

Lebar, Frank M., 1972, Ethnic Group of Ionsular Southeast Asia, Volume I : Indonesia, Andaman Island, and Madagaskar. New Haven : Human Relation, Area Files Press.

Mahadi. 1991. Uraian Singkat tentang Hukum Adat, sejak RR. Tahun 1854. Bandung: Alumni.

Moore, Sally Falk, 1993, Hukum dan Perubahan Sosial: Bidang Sosial Semi-Otonom sebagai Suatu Topik Studi yang tepat. Dalam Ihromi, T.O (Penyunting), Antropologi Hukum. Sebuah Bunga Rampai. Jakarta: Yayasan Obor Indonesia.

Pemerintah Kabupaten Ngada, 2010, Ngada dalam Angka. Bajawa: Pemkab Ngada.

Ter Haar, Bzn, 1960, Begiselen en Stelsel van Het Adatrecht. Dalam Soebekti Poesponoto (penerjemah) Asas-asas dan Susunan Hukum Adat. Jakarta : Pradnja Paramita.

Van Vollenhoven, Cornelis, 1925, Het Adatrecht van Nederlandsch Indie. Jilid I-II. Leiden.

Wellan, J.W.J, 1933, Regeling van de Inheemse Rechtspraak. Wageningen: Veenman. 
Wessing, Robert, 1978, Cosmology and Social Behavior in a West Javanesse Settlement. Ohio University Center for International Studies, South-East Asia Series, No. 47. Athens Ohio: Centre for Southeast Asian Studies. 